\title{
Cytotoxic Effects of White-MTA and MTA-Bio Cements on Odontoblast-Like Cells (MDPC-23)
}

\author{
Fernanda Campos Rosetti LESSA ${ }^{1}$ \\ Andreza Maria Fábio ARANHA ${ }^{1}$ \\ Josimeri HEBLING ${ }^{1}$ \\ Carlos Alberto de SOUZA COSTA ${ }^{2}$ \\ ${ }^{1}$ Department of Orthodontics and Pediatric Dentistry, Araraquara Dental School, \\ São Paulo State University, Araraquara, SP, Brazil \\ ${ }^{2}$ Laboratory of General Pathology and Biomaterials, Department of Physiology and Pathology, \\ Araraquara Dental School, São Paulo State University, Araraquara, SP, Brazil
}

\begin{abstract}
This study evaluated the cytotoxic effects of 2 mineral trioxide aggregate (MTA) cements - White-MTA-Angelus and a new formulation, MTA-Bio - on odontoblast-like cell (MDPC-23) cultures. Twenty-four disc-shaped ( $2 \mathrm{~mm}$ diameter x $2 \mathrm{~mm}$ thick) specimens were fabricated from each material and immersed individually in wells containing $1 \mathrm{~mL}$ of DMEM culture medium for either 24 h or 7 days to obtain extracts, giving rise to 4 groups of 12 specimens each: G1 - White-MTA/24 h; G2 - White-MTA/7 days; G3 - MTA-Bio/24 h; and G4 - MTA-Bio/7 days. Plain culture medium (DMEM) was used as a negative control (G5). Cells at 30,000 cells $/ \mathrm{cm}^{2}$ concentration were seeded in the wells of 24 -well plates and incubated in a humidified incubator with $5 \% \mathrm{CO}_{2}$ and $95 \%$ air at $37^{\circ} \mathrm{C}$ for $72 \mathrm{~h}$. After this period, the culture medium of each well was replaced by $1 \mathrm{~mL}$ of extract (or plain DMEM in the control group) and the cells were incubated for additional $2 \mathrm{~h}$. Cell metabolism was evaluated by the MTT assay and the data were analyzed statistically by ANOVA and Tukey's test $(\alpha=0.05)$. Cell morphology and the surface of representative MTA specimens of each group were examined by scanning electron microscopy. There was no statistically significant difference ( $p>0.05)$ between G1 and G2 or between G3 and G4. No significant difference $(p>0.05)$ was found between the experimental and control groups either. Similar cell organization and morphology were observed in all groups, regardless of the storage periods. However, the number of cells observed in the experimental groups decreased compared to the control group. MTA-Bio presented irregular surface with more porosities than White-MTA. In conclusion, White-MTA and MTA-Bio presented low cytotoxic effects on odontoblast-like cell (MDPC-23) cultures.
\end{abstract}

Key Words: cell culture, MTA, biomaterials, odontoblasts, cytotoxicity.

\section{INTRODUCTION}

Mineral trioxide aggregate (MTA) is a cement composed of hydrophilic microparticles of several mineral oxides, which sets in the presence of water and hardens within less than $4 \mathrm{~h}$ after mixing, creating a practically impermeable barrier (1). In addition to good radiopacity and low solubility, MTA has an initial $\mathrm{pH}$ of 10.2 soon after mixture with water, which increases to approximately 12.5 after $3 \mathrm{~h}$ and then remains stable for prolonged time (1). Previous studies $(2,3)$ have demonstrated the chemical composition of the MTA salt dissolved in water and identified calcium as the main chemical component responsible for the highly alkaline $\mathrm{pH}$ of this material.
As MTA is a dental material indicated for use in intimate contact with periodontal, bone and pulp tissues, it is important to know the cytotoxic effects and the biological properties of the different MTA formulations available in the market. A previous study investigating the reaction of rat connective tissue to implanted dentin tubes filled with either MTA or calcium hydroxide (4) showed the presence of numerous large granulations birefringent to polarized light, which are calcite crystals originated from the reaction of the calcium from the calcium hydroxide with the carbon dioxide from the pulp tissue. In this preliminary study, the results of tissue response were similar for MTA and calcium hydroxide, which may suggest a similar pulp response for 
both materials when applied directly in contact with this specialized connective tissue. For this reason, several in vivo studies $(4,5)$ have evaluated the behavior of MTA in conservative pulpal therapies and have found that the pulp tissue responds favorably to the contact with MTA, with formation of a protective hard tissue barrier, maintenance of normal characteristics and lack of inflammatory processes. In some cases, pulpal therapies with MTA have shown higher success rates than techniques using calcium hydroxide-based materials (6).

MTA undergoes a significant expansion during the setting reaction and thus can be used as a base material for subsequent cavity restoration. Its good adhesion to the dentin walls and improved marginal adaptation reduces the occurrence of marginal microleakage and the penetration of bacteria and their byproducts into the pulp tissue (1). However, MTA can be solubilized when applied close or directly to the pulp tissue in a humid environment. Under these conditions, the setting reaction can be delayed or prevented, allowing leaching or dissolution of chemical components that might cause toxic effects to the pulp cells and influence pulp healing.

Balto (7) evaluated the morphology of human fibroblasts in contact with ProRoot MTA(Dentsply; Tulsa Dental Products, Tulsa, OK, USA) before (fresh) and after hardening $(24 \mathrm{~h})$ and observed that only a small number of viable cells remained adhered to the fresh material and that some cells exhibited morphological alterations. This fact may suggest a possible toxicity of some components released from MTA in contact with cells.

A Brazilian dental company (Angelus Indústria de Produtos Odontológicos Ltda., Londrina, PR, Brazil) has developed white and gray MTA cements (White-MTAAngelus and Gray-MTA-Angelus) and more recently a new formulation, MTA-Bio for different clinical applications in dental practice. According to the manufacturer, MTA-Bio is fully synthesized in a laboratory under highly controlled and segregated conditions to ensure that the final product is free of undesirable contaminant substances, such as arsenic and lead. Due to its alleged high purity and low solubility, MTA-Bio is claimed to have low toxic effect to the pulp cells, allowing for a faster and more effective tissue healing after direct pulp capping or pulpotomy. De-Deus et al. (8) have recently demonstrated that White-MTA-Angelus, MTA-Bio and Portland cement presented similar ability to seal furcal perforations in extracted human molars. Despite the favorable results obtained with the use of conventional
MTA for the conservative treatment of pulp exposures, little is known about its effects in contact with pulp cells, such as odontoblasts. Being a recently developed material, the cytotoxicity of MTA-Bio on pulp cells and its biocompatibility when used as a direct pulp capping material have not yet been demonstrated.

Several methodologies using in vitro tests in cell cultures have been proposed to evaluate the cytotoxicity of dental materials $(9,10)$. Although there is no consensus in the literature about the most indicated cell type for these assessments, odontoblast-like cells (MDPC-23) have been widely used, especially for their odontoblast phenotype (11).

The aims of this preliminary study were: 1 . to evaluate the cytotoxic effects of White-MTA and MTA-Bio extracts on odontoblast-like cell (MDPC-23) cultures, varying the immersion time of the materials in the culture medium; and 2. to analyze the morphology of these cells after contact with the extracts and the specimen surface using scanning electron microscopy (SEM).

\section{MATERIAL AND METHODS}

\section{Cell Culture}

Immortalized cells of the MDPC-23 cell line were defrost and cultured in Dulbecco's Modified Eagle's Medium (DMEM; Sigma Chemical Co., St. Louis, MO, USA) supplemented with $10 \%$ fetal bovine serum (FBS; Gibco, Grand Island, NY, USA), with $100 \mathrm{IU} / \mathrm{mL}$ penicillin, $100 \mu \mathrm{g} / \mathrm{mL}$ streptomycin and $2 \mathrm{mM} / \mathrm{L}$ glutamine (Gibco) in an humidified incubator with $5 \% \mathrm{CO}_{2}$ and $95 \%$ air at $37^{\circ} \mathrm{C}$ (Isotemp; Fisher Scientific, Pittsburgh, PA, USA). The cells were sub-cultured every 3 days until an adequate number of cells were obtained for the study. The cells were seeded $\left(30,000\right.$ cells $\left./ \mathrm{cm}^{2}\right)$ in 60 wells of sterile 24-well plates (Costar Corp., Cambridge, MA, USA), which were maintained in the humidified incubator with $5 \% \mathrm{CO}_{2}$ and $95 \%$ air at $37^{\circ} \mathrm{C}$ for $48 \mathrm{~h}$.

\section{Specimen Preparation}

The compositions, powder-to-liquid ratio and batch number of the two MTA cements evaluated in this study - White-MTA and MTA-Bio (both manufactured by Angelus) - are presented in Table 1.

The tested materials were prepared under aseptic conditions at a ratio of $100 \mathrm{mg}$ of MTA powder to $30 \mu \mathrm{L}$ distilled water, as recommended by the manufacturer. 
Twenty-four disc-shaped specimens ( $2 \mathrm{~mm}$ diameter $\mathrm{x}$ $2 \mathrm{~mm}$ thick) of each material were prepared using 1-mL sterile disposable plastics syringes (Injex; Indústrias Cirúrgicas Ltda., Ourinhos, SP, Brazil). The specimens were placed individually in the wells of sterile 24-well plates for $4 \mathrm{~h}$ at $37^{\circ} \mathrm{C}$ for set of the material and then 1 $\mathrm{mL}$ of DMEM (without FBS) was added to each well. The plates with the specimens immersed in culture medium were placed in the humidified incubator with $5 \%$ $\mathrm{CO}_{2}$ and $95 \%$ air at $37^{\circ} \mathrm{C}$ (Isotemp; Fisher Scientific) for either $24 \mathrm{~h}$ or 7 days to obtain the extracts, that is, culture medium containing the products released by the cements. Four experimental groups of 12 specimens each were formed: G1 - White-MTA/24 h; G2 - White-MTA/7 days; G3 - MTA-Bio/24 h; and G4 - MTA-Bio/7 days. Plain DMEM was used as a negative control (Group 5).

MDPC- 23 cells at 30,000 cells $/ \mathrm{cm}^{2}$ concentration were then seeded in the wells of 3 sterile 24-well plates (Costar) and maintained in the humidified incubator with $5 \% \mathrm{CO}_{2}$ and $95 \%$ air at $37^{\circ} \mathrm{C}$ (Isotemp; Fisher Scientific) for $72 \mathrm{~h}$. After this period, the culture medium was replaced by $1 \mathrm{~mL}$ of 24-h or 7-day extract. The cells were incubated in contact with the extracts for $120 \mathrm{~min}$.

\section{Analysis of Cell Metabolism}

In each group, 10 out of 12 wells were used for

Table 1. Tested materials.

\begin{tabular}{|c|c|c|c|}
\hline $\begin{array}{l}\text { Commercial } \\
\text { brand }\end{array}$ & $\begin{array}{l}\text { Composition } \\
\text { (\%weight) }\end{array}$ & $\begin{array}{l}\text { Powder/liquid } \\
\text { by ratio weight }\end{array}$ & $\begin{array}{c}\text { Batch } \\
\quad \#\end{array}$ \\
\hline White-MTA & $\begin{array}{c}\mathrm{SiO}_{2}, \mathrm{~K}_{2} \mathrm{O}, \\
\mathrm{Al}_{2} \mathrm{O}_{3}, \mathrm{Na}_{2} \mathrm{O}, \\
\mathrm{Fe}_{2} \mathrm{O}_{3}, \mathrm{SO}_{3}, \\
\mathrm{BI}_{2} \mathrm{O}_{3}, \mathrm{MgO}, \\
\mathrm{CaO} \text { insoluble } \\
\text { residues and } \\
\text { crystallized } \\
\text { silicon }\end{array}$ & $\begin{array}{c}0.0925 \mathrm{~g} / 30 \mu \mathrm{L} \\
\text { distilled water }\end{array}$ & 3035 \\
\hline MTA-Bio & $\begin{array}{c}\mathrm{SiO}_{2}, \mathrm{~K}_{2} \mathrm{O} \\
\mathrm{Al}_{2} \mathrm{O}_{3}, \mathrm{Na}_{2} \mathrm{O} \\
\mathrm{Fe}_{2} \mathrm{O}_{3} \\
\mathrm{SO}_{3}, \mathrm{CaO} \\
\mathrm{BI}_{2} \mathrm{O}_{3} \text { and } \\
\text { crystallized } \\
\text { silicon }\end{array}$ & $\begin{array}{c}0.0925 \mathrm{~g} / 30 \mu \mathrm{L} \\
\text { distilled water }\end{array}$ & --- \\
\hline
\end{tabular}

analysis of cell metabolic activity by the cytochemical demonstration of succinic dehydrogenase (SDH) activity, which is a measure of the mitochondrial respiration of cells, using the methyl tetrazolium (MTT) assay (12).

All procedures were performed in a vertical laminar flow chamber. The extracts were aspirated and replaced by $900 \mu \mathrm{L}$ of plain DMEM plus $100 \mu \mathrm{L}$ of the MTT solution ( $5 \mathrm{mg} / \mathrm{mL}$ sterile PBS). The cells were incubated at $37^{\circ} \mathrm{C}$ for $4 \mathrm{~h}$. Thereafter, the culture medium with the MTT solution were aspirated and replaced by $600 \mu \mathrm{L}$ of acidified isopropanol solution $(0.04 \mathrm{~N} \mathrm{HCl})$ in each well to dissolve the violet formazan crystals resulting from the cleavage of the MTT salt ring by the SDH enzyme present in the mitochondria of viable cells. Three $100 \mu \mathrm{L}$ aliquots of each well were transferred to the wells of 96-well plates. Cell viability was evaluated by spectrophotometry as being proportional to the absorbance measured at $570 \mathrm{~nm}$ wavelength with an ELISA plate reader (ELX 800 Universal Microplate Reader; Bio-Tek Instrument Inc., Winooski, VT, USA). For standardization of absorbance reading, the first 2 wells were filled with $100 \mu \mathrm{L}$ of the acidified isopropanol solution to determine the value corresponding to total light passage, that is, the maximum value to reduce cell metabolism. The data from the MTT assay were analyzed statistically by ANOVA and Tukey's test at 5\% significance level. The values obtained from the 3 aliquots were averaged to provide a single value. Then, the inhibitory effect of the different groups on cell mitochondrial activity was calculated and expressed as percentages.

\section{Analysis of Cell Morphology by SEM}

In each group, 2 out of 12 wells were used for analysis MDPC-23 cell morphology after contact with the MTA extracts. For such purpose, sterile 12-mmdiameter cover glasses (Isotemp; Fisher Scientific) were placed on the bottom of the wells of 24-well dishes immediately before seeding of the MDPC- 23 cells $(30,000$ cells $/ \mathrm{cm}^{2}$ ). After $72 \mathrm{~h}$ of incubation, the culture medium of each well was replaced by either the extracts or plain DMEM (negative control) and the plates were maintained for additional $120 \mathrm{~min}$ in the incubator.

After contact of the MDPC-23 cells with the extracts obtained from White-MTA(G1 and G2), MTABio (G3 and G4) and plain DMEM (G5), the extracts and the DMEM were aspirated, the cover glasses were placed in new 24-well plates and the cells that remained 
adhered to glass surface were washed with PBS. Next, the cover glasses with the adhered cells were fixed in $2.5 \%$ glutaraldehyde solution ( $1 \mathrm{~mL}$ per well) for $2 \mathrm{~h}$, washed 3 times with $1 \mathrm{~mL}$ PBS ( 5 min each), post-fixed with $1 \%$ osmium tetroxide for $1 \mathrm{~h}$, washed 2 times with $1 \mathrm{~mL}$ PBS ( 5 min each) and 2 times with $1 \mathrm{~mL}$ deionized water (15 min each), dehydrated in a series of increasing ethanol concentrations, immersed in 1.1.1.3,3,3-hexamethyldisilazane (HMDS; Acros Organics, Springfield, NJ, USA) with three 20-min immersions and finally maintained in a desiccator for $12 \mathrm{~h}$. After that, the cover glasses were mounted on metallic stubs, sputter-coated with gold and cell morphology was examined with a scanning electron microscope (ZEISS; model DSM940A, Oberkochen, Germany).

In addition, the surface of 2 representative specimens of each experimental group was also subjected to technical processing and examined under SEM.

\section{RESULTS}

\section{Analysis of Cell Metabolism (MTT Assay)}

The descriptive data for the SDH enzyme activity quantified by the MTT assay are presented in Figure 1.

The data obtained from the statistical analysis showed no statistically significant difference $(p>0.05)$ between G1 and G2 or between G3 and G4. No significant difference $(p>0.05)$ was found either between the experimental and control groups. However, application of the Tukey's test to evaluate the influence of the material/extract time interaction separately for both materials

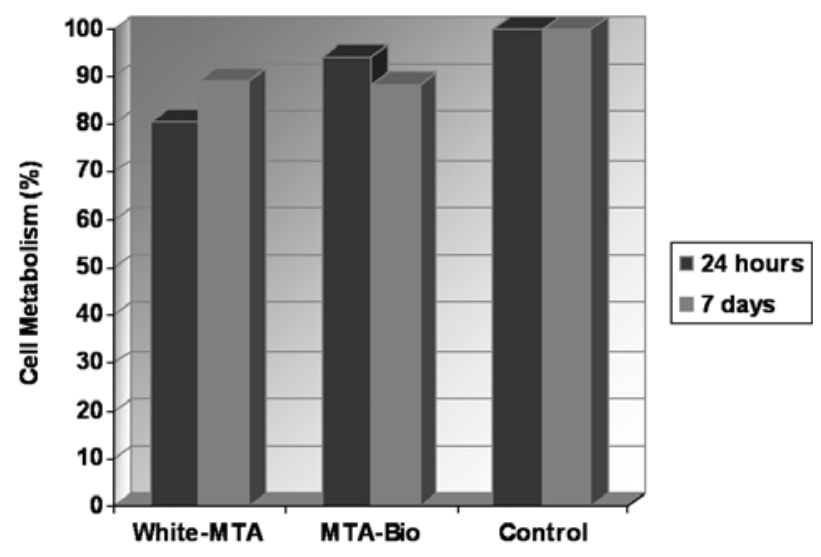

Figure 1. Cell metabolism according to MTA cement and extract obtainment time. showed tendency $(\mathrm{p}<0.05)$ of the 24 -h extracts of MTABio to be more toxic to the MDPC-23 cells than the extracts collected from White-MTA in the same period.

For the 24-h extracts, considering the negative control (G5 - DMEM) as having 100\% cell metabolism, the metabolic activity of the MDPC-23 cells that remained adhered to the glass substrate in G1 and G2 decreased to $94 \%$ and $80.7 \%$, respectively. For the 7 -day extracts, considering the negative control (G5) as having $100 \%$ cell metabolism, the metabolic activity of MDPC23 cells that remained adhered to glass substrate in G2 and G4 decreased to $88.3 \%$ and $89.1 \%$, respectively.

\section{Analysis of Cell Morphology by SEM}

The SEM analysis showed that the negative control group (G5) presented a large number of MDPC23 cells adhered to the glass substrate. These cells exhibited typical morphological characteristics as they were spindle-shaped and exhibited numerous thin and long cytoplasmic processes originating from the cell membrane, which seemed to be keeping the cells attached to the glass substrate. The cells were organized in epithelioid nodules and near confluence (Fig. 2).

When the cells were exposed to the MTA extracts, similar cell organization was observed in all experimental groups (G1 to G4). There were no statistically significant differences $(\mathrm{p}>0.05)$ among these groups regarding the decrease of cell metabolism for both extract times ( 24 $\mathrm{h}$ and 7 days). However, there was a smaller number of cells composing the epithelioid nodules adhered to the glass substrate compared to the negative control group (Fig. 3). Some cells that remained adhered to the glass were small-sized, round-shaped and presented few or no cytoplasmic process originating from their membrane.

\section{Analysis of Specimen Surface by SEM}

MTA-Bio specimens presented a more irregular and porous surface than that of White-MTA specimens, for both 24-h and 7-day extracts (Figs. 4 and 5). MTA-Bio presented a less homogenous surface than White-MTA.

\section{DISCUSSION}

Several methodologies have been proposed to determine the cytotoxic effects of dental materials. In this study, cell metabolic activity was evaluated by analysis of 
the SDH activity, which is a measure of the mitochondrial respiration of the cells in contact with extracts obtained from the tested MTA cements. The MTT assay used for such purpose is a colorimetric method in which MTT salt is reduced into a soluble formazan product and has

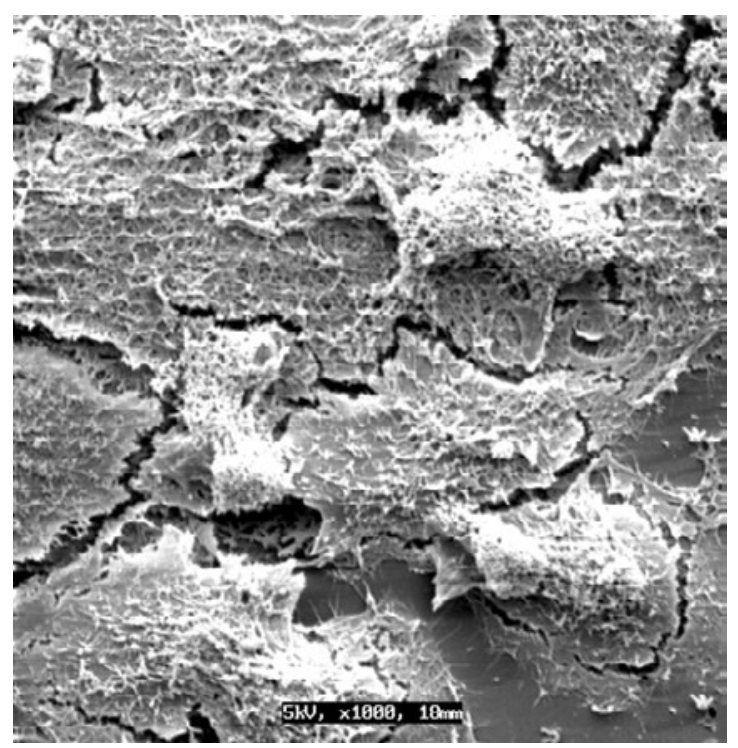

Figure 2. SEM micrographs of the negative control group (Plain DMEM culture medium). MDPC-23 cells adhered to the cover glass, near confluence and exhibiting numerous cytoplasmic processes originated from the cell membrane $(\times 1.000$ magnification $)$. been described in detail more than two decades ago (12). According to Schweikl and Schmalz (13), the choice for the type of assay should be based on the chemical nature of the material to be tested. Since MTA is composed of a range of hydrophilic microparticles from several mineral oxides, capable to release ionic components, the MTT assay was selected to evaluate the intracellular enzymatic activity. This methodology for analysis of cytotoxicity has been widely used to evaluate various dental materials, such as adhesive systems, composite resins, different types of cements, irrigating solutions and cavity cleansers $(9,10)$.

Since MTA is indicated for several conservative pulpal therapies in primary and permanent teeth, such as direct pulp capping and pulpotomies, it is important to know its cytotoxic effects, especially on pulp cells. Odontoblasts are typical cells of the pulp tissue and are organized in a monolayer that underlies the dentin, being therefore the first cells to be damaged by potentially cytotoxic compounds released from dental materials. Due to their location and functions of synthesis, secretion and deposition of dentin matrix, odontoblasts have a role in the healing process of the pulp-dentin complex when the pulp is subjected to mechanical, thermal or chemical stress conditions (14). This is the reason why immortalized cells of the odontoblast-like cell line (MDPC-23) were selected for the present study. These
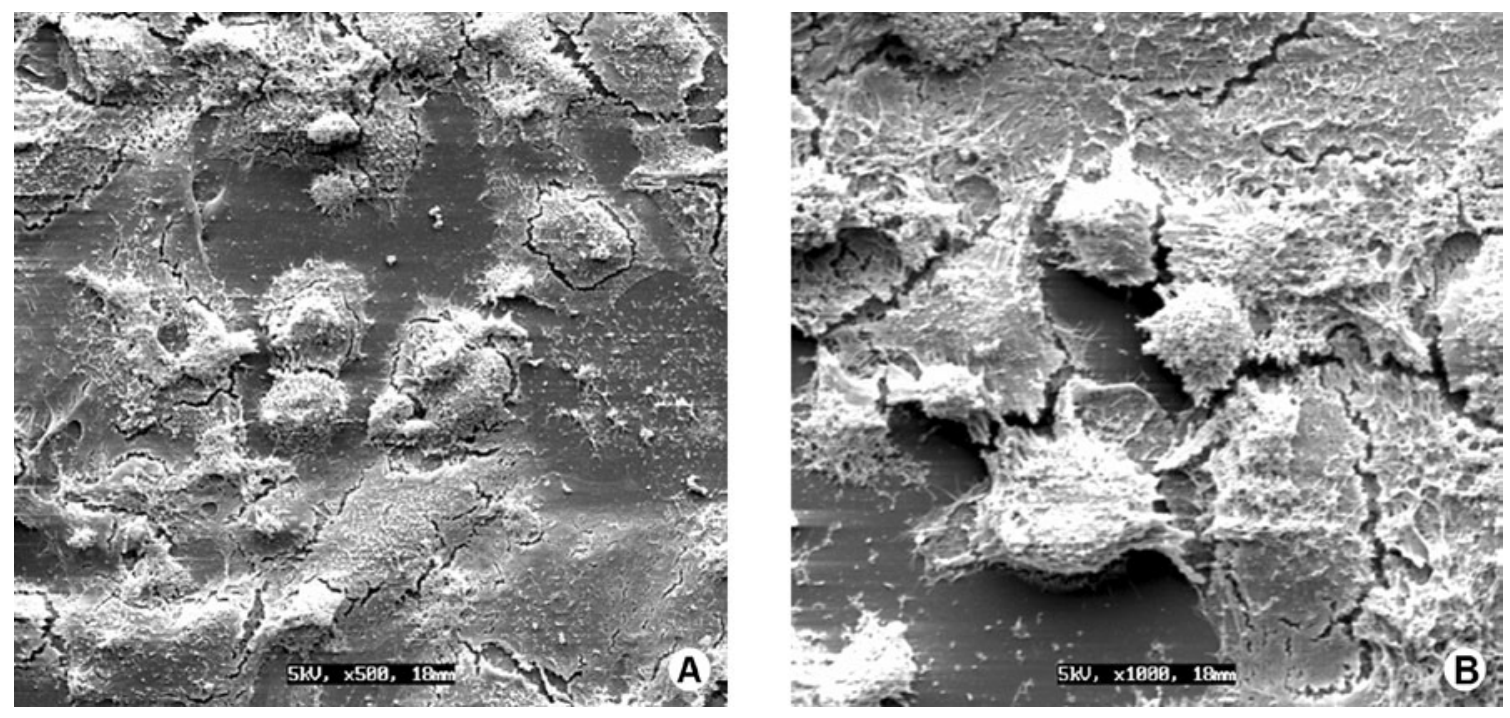

Figure 3. SEM micrographs of G3 and G1. MDPC-23 cells adhered to the cover glass after exposure to the 24 h-extracts obtained from MTA-Bio (A; $\times 500$ magnification) and White-MTA $(\mathrm{B} ; \times 1000$ magnification) showing the presence of a smaller number of cells forming the epithelioid nodules adhered to the glass substrate. Rests of cytoplasmic processes from cells that detached from the glass substrate can also be observed. 
cells have been introduced to dental science to analyze the tissue healing process and the different mechanisms by which dental materials or substances leached from them cause cell damage or death (11).

The present study evaluated a commercial and an experimental MTA cement manufactured by a Brazilian dental company, White-MTA and MTA-Bio, respectively. Several studies have been developed to compare the physical and biological characteristics of the conventional cements currently used for a number of clinical procedures including conservative pulpal therapy (15). Oviir et al. (16) have demonstrated that white MTA was more biocompatible than gray MTA, increasing significantly the proliferation of OCCM-30 cementoblasts on its surface. Those authors attributed this result to the different components present in the
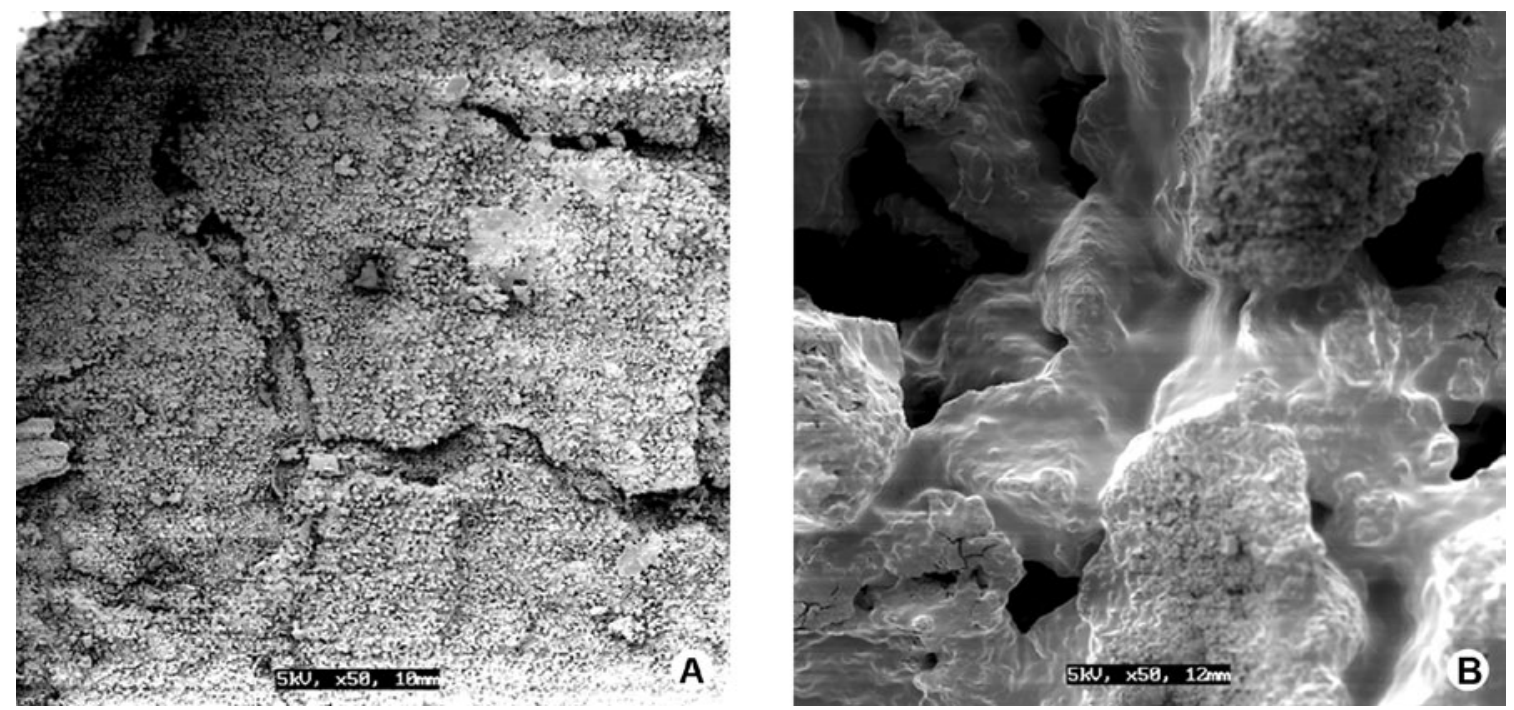

Figure 4. SEM micrographs of a specimen surface from G3 (MTA-Bio/24 h). A: ( $\times 50$ magnification): The surface of the specimen is not homogenous. B: Greater magnification of "A" $(\times 100$ magnification $)$ showing great porosity on specimen surface.
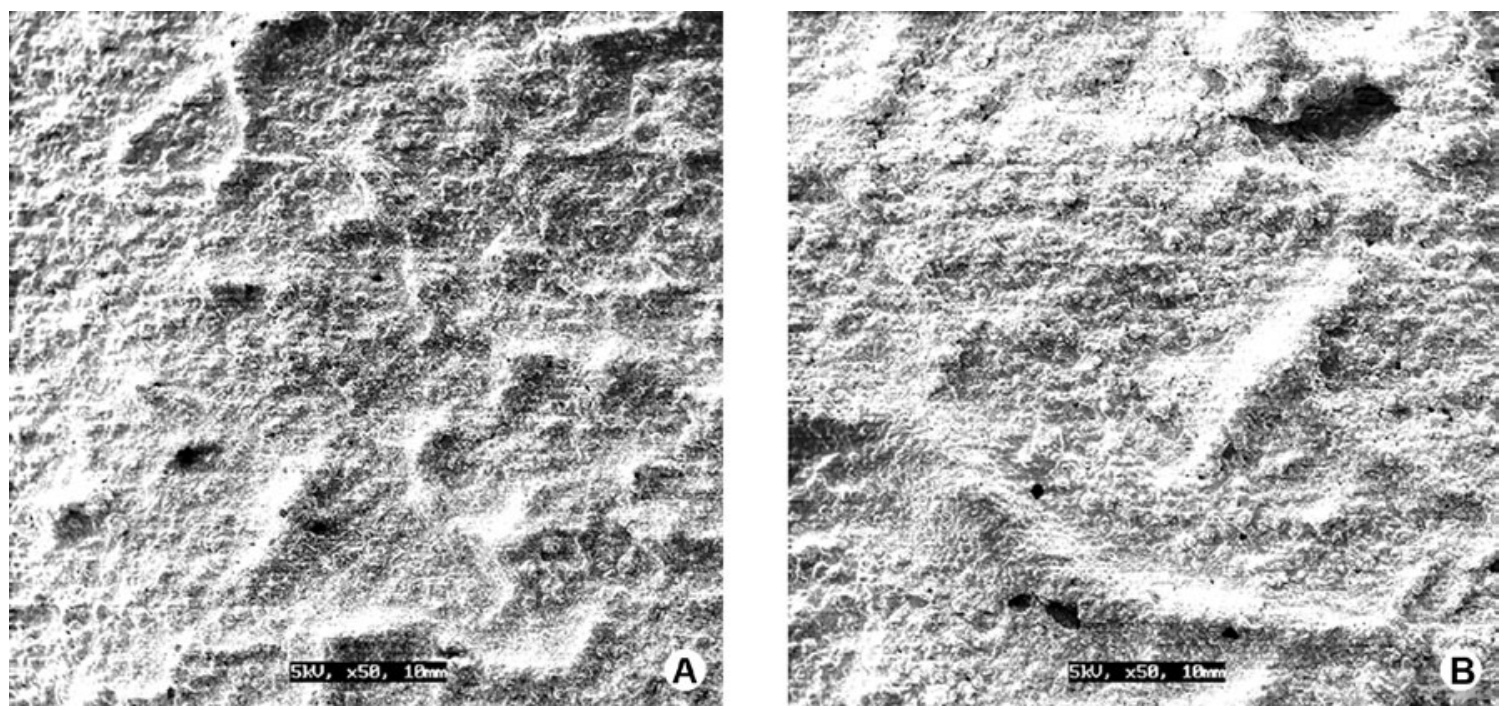

Figure 5. SEM micrographs of a specimen surface from G2 (MTA-White/7 days). The surface of the specimen is very homogenous (A; $\times 50$ magnification) and exhibits only little porosity $(\mathrm{B} ; \times 50$ magnification). 
formulation of the cements.

Both materials evaluated in the present study are white cements and have similar chemical composition to that of the MTA cement evaluated by Oviir et al. (16) (ProRoot MTA). However, MTA-Bio has higher calcium oxide $(\mathrm{CaO})$ content than White-MTA and does not present magnesium oxide $(\mathrm{MgO})$ in its formulation. Free $\mathrm{CaO}$ combines with water in a similar manner as $\mathrm{MgO}$, leading to the setting expansion of the material. MTA-Bio has a high setting expansion due to its higher $\mathrm{CaO}$ content. According to the manufacturer, the higher concentration of this component in MTA-Bio would result in a greater release of calcium ions to the exposed pulp tissue, accelerating tissue healing, which is characterized by the differentiation of pulp cells in new odontoblasts and synthesis of dentin matrix for further calcification. Calcium participation in tissue healing and the increase of cell activity regarding the synthesis of alkaline phosphatase have been described in the literature (17). The greater release of components from MTA-Bio in an aqueous medium could be characterized by the analysis of the surface of the specimens prepared with the material immersed in culture medium. The White-MTA specimens presented a homogeneous surface with very little porosity. However, confirmation of a greater or lower release of components from the materials, especially $\mathrm{CaO}$, when immersed in the culture medium, would only be possible by means of an atomic absorption analysis.

In spite of the important role of calcium ions in the tissue repair process, a high release rate of these ions in the culture medium may result in irreversible damage to the cell culture. Therefore, in the present study, MTA-Bio was expected to present more intense cytotoxic effects than White-MTA. However, no significant differences were found between the materials with either extract time or the material/extract time interaction. It may be suggested that even after 7 days of specimen immersion in the culture medium the release of toxic substances was similar to that observed when a shorter extract time was established $(24 \mathrm{~h})$. This lack of interaction between the extract time and the cytotoxic effects of the material on the cell culture has been previously demonstrated (18). Those authors reported that exposure of the cells to 1-, 3-, 7-, 14- and 28-day white MTA extracts for 24 $\mathrm{h}$ caused an increase in cell metabolic activity rather than cell damage.

In the present study, the surface of the MTA-Bio specimens was more porous than that of White-MTA, as revealed by the SEM analysis. The possible solubilization of MTA-Bio in contact with the moist dental pulp or the humid environment close to this tissue could allow the leaching of some components from this material that are toxic to the pulp cells and may unchain a persistent inflammatory response. According to the manufacturer, the porosities or irregularities found in MTA-Bio may be related to the higher free calcium content of this material compared to White-MTA. The goal is to afford a greater availability of this chemical compound to the tissues. Both tested materials presented low cytotoxic effect on the MDPC-23 cells. Further in vivo studies are necessary to determine if MTA-Bio actually provides a greater release of calcium ions to the tissues.

The low toxic effect of the different types of MTA cements available in the market has been widely reported. The proliferation of MDPC-23 and OD-21 pulp cells (19), ligament periodontal fibroblasts (17) and MG-63 osteoblasts (20) in contact with MTA has been demonstrated. Koh et al. (20) found that cells exposed to MTA presented normal morphology, growing in intimate contact with cement. This suggests that the original formulations of the first MTA cements developed in the last decades already presented little aggressive effects on cell cultures. In this study, the morphological analysis showed that, for both cements, some MDPC-23 cells that remained adhered to the glass substrate were round-shaped and presented few or no cytoplasmic processes. In rare situations, the MDPC-23 cells in contact with the 24- and 7-day extracts obtained from the tested materials exhibited thin cytoplasmic processes keeping the cell body adhered to the glass substrate. In addition, the MTT assay showed that both White-MTA and MTA-Bio presented low cytotoxic effects. It should be emphasized that the results obtained from preliminary cytotoxicity tests have limitations with respect to their direct correlation with clinical situations. Therefore, further studies employing White-MTA and MTA-Bio as pulp capping agents are required to demonstrate pulp response to the direct application of these cements.

According to the experimental conditions and the methodology employed in the present in vitro study, it may be concluded that: 1 . White-MTA and MTA-Bio presented low cytotoxic effects on odontoblast-like cell (MDPC-23) cultures, with no significant difference between the materials; 2 . The time of immersion of the specimens in the culture medium to produce extracts (24 
h or 7 days) did not have a significant influence on the cytotoxicity of the cements; 3 . Structurally, MTA-Bio appeared as a more porous cement after immersion in aqueous medium than White-MTA.

\section{RESUMO}

Este estudo avaliou o efeito citotóxico de dois cimentos MTA MTA Branco-Angelus e uma nova formulação, MTA-Bio - sobre células odontoblastóides (MDPC-23) mantidas em cultura. Vinte e quatro espécimes padronizados ( $2 \mathrm{~mm}$ diâmetro x $2 \mathrm{~mm}$ largura) foram confeccionados de cada material e imersos individualmente em compartimentos contendo $1 \mathrm{~mL}$ de meio de cultura DMEM por $24 \mathrm{~h}$ ou 7 dias para obtenção dos extratos, formando 4 grupos de 12 espécimes cada: G1 - MTA-Branco/24 h; G2 - MTA-Branco/7 dias; G3 - MTA-Bio/24 h; e G4 - MTA-Bio/7 dias. Meio de cultura puro (DMEM) foi utilizado como controle negativo (G5). Células na concentração de 30.000 células $/ \mathrm{cm}^{2}$ foram semeadas nas placas de 24 compartimentos e incubadas em incubadora com $5 \% \mathrm{CO}_{2} \mathrm{e}$ $95 \%$ ar a $37^{\circ} \mathrm{C}$ por $72 \mathrm{~h}$. Após esse período, o meio de cultura de cada compartimento foi substituído por $1 \mathrm{~mL}$ do extrato (ou DMEM puro no grupo controle) e as células foram incubadas pelo período adicional de $2 \mathrm{~h}$. O metabolismo celular foi avaliado pelo teste do MTT e os dados foram analisados estatisticamente pelo teste de ANOVAe Tukey $(\alpha=0,05)$. A morfologia celular e da superfície dos espécimes de MTA representativos de cada grupo foram avaliados em microscopia eletrônica de varredura. Não houve diferença estatisticamente significante $(\mathrm{p}>0,05)$ entre os gurpos $\mathrm{G} 1$ e $\mathrm{G} 2$ ou entre G3 e G4. Não foi encontrada diferença estatística $(p>0,05)$ entre os grupos experimentais e controle. Morfologia e organização celular semelhante foram observadas em todos os grupos, independente do período de extração. Entretanto, o número de células observado nos grupos experimentais diminui quando comparado ao grupo controle. MTA-Bio apresentou uma superfície irregular com mais porosidades que o MTA-Branco. Pode-se concluir que os cimentos MTA-Branco e MTA-Bio apresentaram reduzido efeito citotóxico sobre células odontoblastóides (MDPC-23) mantidas em cultura.

\section{ACKNOWLEDGEMENTS}

The authors thank the company Angelus Indústria de Produtos Odontológicos Ltda., Londrina, PR, Brazil, for supplying the MTA cements used in this study. The study was partially supported by the São Paulo State Research Foundation/FAPESP(Grant\#04/00246-0) and by the Brazilian National Council for Scientific and Technological Development/CNPq (Grant \#302575/2004-9). The authors are also indebted to Prof. Dr. Elliot W. Kitajima, head of NAP/ MEPA-ESALQ/USP, for use of the electron microscopy lab facilities.

\section{REFERENCES}

1. Torabinejad M, Hong CU, McDonald F, Pitt Ford TR. Physical and chemical properties of a new root-end filling material. J Endod 1995;21:349-353.

2. Fridland M, Rosado R. Mineral trioxide aggregate (MTA)-Solu- bility and porosity with different water-to-powder ratios. J Endod 2003;29:814-817.

3. Oliveira MG, Xavier CB, Demarco FF, Pinheiro AL, Costa AT, Pozza DH. Comparative chemical study of MTA and Portland cements. Braz Dent J 2007;18:3-7.

4. Holland R, de Souza V, Nery MJ, Otoboni Filho JA, Bernabe PF, Dezan Junior E. Reaction of rat connective tissue to implanted dentin tubes filled with mineral trioxide aggregate or calcium hydroxide. J Endod 1999;25:161-166.

5. Fernández-Yáñez Sánchez A, Leco-Berrocal MI, Martínez-González JM. Metaanalysis of filler materials in periapical surgery. Med Oral Patol Oral Cir Bucal 2008;13:E180-E185.

6. Chacko V, Kurikose S. Human pulpal response to mineral trioxide aggregate (MTA): a histologic study. J Clin Pediatr Dent 2006;30:203-209.

7. Balto HA. Attachment and morphological behavior of human periodontal ligament fibroblasts to mineral trioxide aggregate: a scanning electron microscope study. J Endod 2004;30:25-29.

8. De-Deus G, Reis C, Brandão C, Fidel S, Fidel RA. The ability of Portland cement, MTA, and MTA Bio to prevent through-andthrough fluid movement in repaired furcal perforations. J Endod 2007;33:1374-1377.

9. Hebling J, Lessa FCR, Nogeira I, Carvalho RM, Costa CAS. Cytotoxicity of resin-based light-cured liners. Am J Dent 2009;22:137142.

10. Lima AF, Lessa FCR, Mancini MN, Hebling J, Costa CAS, Marchi GM. Trandentinal protective role of sodium ascorbate against the cytopathic effects of $\mathrm{H} 2 \mathrm{O} 2$ released from bleaching agents. Oral Surg Oral Med Oral Pathol Oral Radiol Endod 2010;109:e70-e76.

11. Hanks CT, Sun ZL, Fang DN, Edwards CA, Wataha JC, Ritchie $\mathrm{HH}$, et al.. Cloned 3T6 cell line from CD-1 mouse fetal molar dental papillae. Connect Tissue Res 1998;37:233-249.

12. Coldebella CR, Ribeiro APD, Sacono NT, Trindade FZ, Hebling J, Costa CAS. Indirect cytotoxicity of hydrogen peroxide bleaching gel on cultured odontoblast-like cells. Braz Dent J 2009;20:267274.

13. Schweikl H, Schmalz G. Toxicity parameters for cytotoxicity testing of dental materials in two different mammalian cell lines. Eur J Oral Sci 1996;104:292-299.

14. Araña-Chavez VE, Massa LF. Odontoblasts: the cells forming and maintaining dentine. Int J Biochem Cell Biol 2004;36:1367-1373.

15. Reston EG, Costa CAS. Scanning electron microscopy of the hard tissue barrier after pulp capping with calcium hydroxide, mineral trioxide aggregate (MTA) and ProRoot MTA. Aust Endod J 2009;35:78-84.

16. Oviir T, Pagoria D, Ibarra G, Geurtsen W. Effects of gray and white mineral trioxide aggregate on the proliferation of oral keratinocytes and cementoblasts. J Endod 2006;32:210-213.

17. Bonson S, Jeansonne BG, Lallier TE. Root-end filling materials alter fibroblast differentiation. J Dent Res 2004;83:408-413.

18. Camilleri J, Montesin FE, Di Silvio L, Pitt Ford TR. The chemical constitution and biocompatibility of accelerated Portland cement for endodontic use. Int Endod J 2005;38:834-842.

19. Moghaddame-Jafari S, Mantellini MG, Botero TM, McDonald NJ, Nor JE. Effect of ProRoot MTA on pulp cell apoptosis and proliferation in vitro. J Endod 2005;31:387-391.

20. Koh ET, McDonald F, Pitt Ford TR, Torabinejad M. Cellular response to mineral trioxide aggregate. J Endod 1998;24:543-547.

Accepted March 17, 2010 